\title{
Genetic Variation in Date Palms Propagated from Offshoots and Tissue Culture
}

\author{
Vyacheslav Gurevich, Uri Lavi, and Yuval Cohen ${ }^{1}$ \\ Department of Fruit Tree Sciences, Agriculture Research Organization, Volcani Research Center, Bet \\ Dagan, 50250, Israel
}

\begin{abstract}
Additional INDEX wORds. AFLP, Phoenix dactylifera, polymorphism, somaclonal variation
Abstract. Date palm (Phoenix dactylifera L.) is a major tree crop in arid regions of the Middle East and North Africa, having an important impact on the economy of many countries in these regions. Date palms are traditionally propagated through offshoots. The development of propagation methods through tissue culture resulted in massive expansion of date palm plantations. While most trees generated from tissue culture are normal and true-to-type, several typical abnormal phenotypes are detected. The present study applies amplification fragment length polymorphism (AFLP) analysis to characterize the genetic variation of two elite date cultivars, 'Barhee' and 'Medjool', as well as male clones, propagated from offshoots and through tissue culture. The two cultivars have very distinct AFLP band patterns. Most offshoots, as well as the tissue culture-propagated plants, have very similar band patterns, demonstrating a low level of genetic variation. However, a significant level of genetic variation was detected among 'Medjool' plants generated from tissue culture. Several phenotypically abnormal trees were characterized by unique and different AFLP band patterns. The male clones are characterized by a high level of polymorphic bands. Genetic variation was also detected between various tissues of variegated 'Medjool' trees propagated from tissue culture. The significance of these results, regarding the mechanism of the phenomenon and its relevance to agricultural practice, is discussed.
\end{abstract}

Dates are dioecious fruit trees, belonging to the family Arecaceae (Coryphoideae) having $2 \mathrm{n}=36$ chromosomes (Barrow, 1998). Date is a major fruit crop in arid regions of the Middle East and North Africa, as well as other arid regions in the world. Date palms have grown in oases in desert regions in Israel for thousands of years. Elite cultivars from various origins (including Iraqi, Moroccan, Tunisian, and Egyptian cultivars) were introduced to the country during the past century, serving as the basis for the modern Israeli date industry.

The traditional method of date palm propagation is by offshoots. However, this method is limited by the small number of offshoots generated on each tree (1-20, depending on the cultivar). Therefore, this propagation method does not satisfy the large need for plant material (Zaid and De Wet, 1999) and thus limits the expansion of date palm plantations. Several methods for in vitro propagation through tissue culture were developed for date palm. These methods have several advantages in comparison to propagation by offshoots: large-scale multiplication, no seasonal effect on plant source, and easy and safe exchange of plant material between different regions without the risk of contamination (Zaid and De Wet, 1999).

Vegetative propagation by either offshoots or tissue culture should result in "progeny" which are identical to each other and to their "mother" tree (true to type). However, it is well known that somaclonal variation does occur in plants propagated via tissue culture and the resulting plants are not always identical (Kaeppler et al., 2000). Abnormal date palms originated from tissue culture are commonly detected. Typical phenotypes include leaves with wide leaflets, slow growth rate and development, variegation (leaf

Received for publication 19 Apr. 2004. Accepted for publication 19 June 2004 The research was funded by a research grant of the Chief Scientist of the Israeli Ministry of Agriculture and the Israeli Fruit Board. Contribution from the Agricultural Research Organization (ARO), The Volcani Center, Bet-Dagan, Israel, No. 110/2004. We wish to thank Effraim Tripler for technical help.

${ }^{1}$ To whom reprint requests should be addressed. Phone: 972-3-9683407; fax: 972-3-9669583; e-mail: vhyuvalc@volcani.agri.gov.il sectors with different color), inability to form inflorescences, and low levels of fruit setting (McCubbin et al., 2000).

Many trees belonging to 'Barhee' and 'Hallas' cultivars that originated from tissue culture have low levels of fruit setting. Most of the flowers of these trees turn into three-carpel parthenocarpic fruits. Multi-carpel flowers and fruitlets (with up to six or seven carpels, instead of the normal three-carpel flowers) were also detected (Al-Wasel, 2000; Cohen et al., 2004; Djerbi, 2000). This phenomenon characterizes about 2000 'Barhee' and 'Hallas' date trees in Israel and many thousands in other countries, including Jordan, Namibia, and Saudi Arabia. The abnormal parthenocarpic fruits are not suitable for marketing, thus imposing a major economic loss.

Another off-type phenotype commonly detected in date palms of the 'Medjool' cultivar from tissue culture is characterized by severe growth retardation. These trees remain stunted, and produce only very few leaves. About 8000 young 'Medjool' trees in Israel have this characteristic phenotype.

Several molecular methods were used for assessment of genetic variation of date palms. Differences between cultivars were detected by isoenzymes (Saker et al., 2000), restriction fragment length polymorphism (RFLP) (Corniquel and Mercier, 1994), random amplified polymorphic DNA (RAPD) (Corniquel and Mercier, 1994; Saker and Moursi, 1999; Sedra et al., 1998), AFLP (Cao and Chao, 2002; Devanand and Chao, 2003), and representional difference analysis (RDA) (Vorster et al., 2002). These tools also served for estimation of genetic distances between various date cultivars from different regions in the world (Al-Khakifa and Askari, 2003; Cao and Chao, 2002; Corniquel and Mercier, 1994; Saker and Moursi, 1999; Sedra et al., 1998).

Some of the analyses were carried out on tissue culture-originated trees. These studies included phenotypic characterization, isoenzymes (Azeqour et al., 2002), and RAPD analyses (Saker et al., 2000). Genetic variations were detected between plantlets phenotypically different at the tissue culture or hardening stages. However, these studies did not reveal genetic variation between plantlets phenotypically similar at these early stages. 
Polymorphism was detected within the cultivars Barhee, Deglet Noor, and Medjool propagated from offshoots using RAPD analysis (Corniquel and Mercier, 1994). Recently, a detailed analysis on the genetic variation within date palms of the same cultivar propagated from offshoots was performed using AFLP(Devanand and Chao, 2003). A low level of genetic variation was detected within 'Deglet Noor' accessions, while a high level of genetic variation was found within various 'Medjool' trees collected in the United States.

In this study, we applied AFLP analysis (Vos et al., 1995) to characterize the genetic variation of date palms from 'Barhee', 'Medjool', and male trees grown in Israel. This analysis was carried out on trees originated from both offshoots and tissue culture.

\section{Materials and Methods}

Plant material. Leaf samples from 29 'Barhee' and 28 'Medjool' trees were collected from different orchards and nurseries in Israel. The various trees included offshoots and tissue culture-propagated trees (from several tissue culture laboratories) having both normal and offtype phenotypes (Table 1). Leaf samples from 33 male trees were collected from two plantations (Yotvata in southern Israel and Beit-Zera near the Sea of Galilee).

DNA EXTRACTION AND GENERATION OF AFLP BAND PATTERNS. Total DNA was isolated from leaves and roots using a hexadecyltrimethylammonium bromide (CTAB) extraction method (Aitchitt et al., 1993). DNA was analyzed on a $0.7 \%$ agarose gel. Generation of AFLP band patterns (Vos et al., 1995) was modified according to Kashkush (Kashkush et al., 2001). Genomic DNA $(0.5 \mu \mathrm{g})$ was digested at $37^{\circ} \mathrm{C}$ for $3 \mathrm{~h}$ and ligated to specific adaptors. The restriction-ligation reaction contained three units (U) MseI, 10 U EcoRI, 120 U T4-DNA ligase (New England Biolabs, Beverly. Mass.), 5 pmole EcoRI-adaptor, 50 pmole $M s e I$ adaptor (see Table 2), $1 \mu \mathrm{L}$ of 0.5 $\mathrm{M} \mathrm{NaCl}, 5 \mu \mathrm{g}$ bovine serum albumin (BSA), and 1X DNA ligase buffer in a final volume of $10 \mu \mathrm{L}$. The digested-ligated DNA was diluted 1:10 with double-distilled $\mathrm{H}_{2} \mathrm{O}$.

Preselective amplification was performed with primers complementary to the adaptor sequences (Table 2). The polymerase chain reaction (PCR) contained $20 \mathrm{ng}$ of restricted-ligated DNA, 10 pmole EcoRI primer, 10 pmole MseI primer, 1 U Taq DNA polymerase (Promega Life Science, Madison, Wis.), $2 \mu \mathrm{L}$ of $10 \mathrm{X}$ Taq DNA polymerase buffer (Promega), $2 \mu \mathrm{L}$ of $25 \mathrm{mM} \mathrm{MgCl}_{2}$, and $0.8 \mu \mathrm{L}$ of $2.5 \mathrm{~mm}$ dNTPs in a final volume of $20 \mu \mathrm{L}$. The PCR conditions were 20 cycles of $30 \mathrm{~s}$ at $94^{\circ} \mathrm{C}, 60 \mathrm{~s}$ at $56^{\circ} \mathrm{C}$, and $60 \mathrm{~s}$ at $72{ }^{\circ} \mathrm{C}$. After preamplification, the PCR products were diluted 1:20 with double-distilled $\mathrm{H}_{2} \mathrm{O}$.

The end-labeling reaction of the EcoRI primer contained: 180 pmole $E c o R I$ primer, $100 \mu \mathrm{Ci} \gamma$-33P ATP, $20 \mathrm{U}$ T4 polynucleotide
20-21

$22-23$

60

24-27

28

29-31

32

$33-34$

35-38

39-42

44

45-46

47

48

49

50-51

52-54

55

57

59

M1-M10

M11-M12

M13-M14

M15-M16

M17-M18

M19-M23

M24-M25

M26-M27

M28-M29

M30-M31

M32-M33
Table 1. 'Barhee', 'Medjool', and various male date palms propagated from offshoots (OS) or produced by different tissue culture companies [(TC) the producing laboratory is numbered in parentheses] characterized in this study.

\begin{tabular}{llllcl}
\hline $\begin{array}{l}\text { Accession } \\
\text { no. }\end{array}$ & Cultivar & $\begin{array}{c}\text { Propagation } \\
\text { origin }\end{array}$ & Orchard & year & Phenotype \\
\hline $1-3$ & Barhee & OS & Yavniel & 2002 & Normal \\
$4-5$ & Barhee & OS & Beit Zera & 1992 & Normal \\
$6-10$ & Barhee & OS & Yotvata & 1992 & Normal \\
$11-13$ & Barhee & TC $(1)$ & Yotvata & 1999 & Low fruit setting \\
14 & Barhee & TC $(1)$ & Beit Zera & 1994 & Normal \\
15 & Barhee & TC $(1)$ & Beit Zera & 1994 & Low fruit setting \\
$16-17$ & Barhee & TC $(1)$ & Yotvata & 1993 & Low fruit setting \\
18 & Barhee & TC $(2)$ & Yotvata & 1999 & Normal \\
19 & Barhee & TC $(2)$ & Yotvata & 1999 & Low fruit setting
\end{tabular}

Barhee

Barhee

Barhee

Barhee

Barhee

Medjool

Medjool

TC (2)

$\mathrm{TC}(3)$

TC (3)

TC (4)

TC (4)

OS

OS of a

TC (2)

Medjool

Medjool

Medjool

Medjool

OS

OS

TC (5)

TC (2)

Medjool

TC (2)

Medjool

TC (2)

Medjool

TC (2)

Medjool

Medjool

Medjool

Medjool

Medjool

TC (2)

TC (2)

TC (6)

TC (7)

TC (7)

Medjool

TC (2)

male

OS

male

male

male

male

male

TC (2)

$\mathrm{TC}(2)$

TC (2)

TC (2)

OS

Beit Zera

Beit Zera

Beit Zera

1999

Yavniel

Yavniel

Yavniel

Shaar Golan

Shaar Golan

Yotvata

Yotvata

2000

2000

1999

1999

2002

1999

1996

Adult

1999

2001

Yavniel

2001

Shaar Golan

1996

Shaar Golan 1996

Yotvata

2001

Yotvata

Yavniel

Havat Eden

2002

2001

Havat Eden

1982

male OS

male

OS
OS

male

OS

male

OS

male

OS
Nursery

Yotvata

Ketura

Ketura

Beit Zera

Beit Zera

Beit Zera

Beit Zera

Beit Zera

Beit Zera

Beit Zera

Beit Zera
Yavniel
Wide leaflets

Multiple carpels

Normal

Normal

Dense leaflets with yellow tips

Normal

Normal

Normal

Telaviopsis symptoms

Normal

Abnormality of OS growing

Dense leaflets with yellow tips

Growth retardation

Normal

Low fruit setting, delayed ripening

Variegation (leaves

with yellow sectors)

Different unknown

individuals

TC Clone 1

TC Clone 2

TC Clone 2

TC Clone 3

Different unknown

individuals

OS clone 4

OS clone 5

OS clone 6

OS clone 7

OS clone 8 kinase, and $10 \mu \mathrm{L}$ of $5 \mathrm{X}$ polynucleotide kinase buffer in a final volume of $50 \mu \mathrm{L}$. Samples were incubated at $37^{\circ} \mathrm{C}$ for $1 \mathrm{~h}$, then heated to $70{ }^{\circ} \mathrm{C}$ for $10 \mathrm{~min}$.

The selective-amplification reaction contained $4 \mu \mathrm{L}$ of diluted template DNA from the preselective amplification, 3.6 pmole of labeled EcoRI primer, 10 pmole MseI primer, 1 U Taq DNA polymerase (Promega), $2 \mu \mathrm{L}$ of 10X Taq DNA polymerase buffer (Promega), $2 \mu \mathrm{L}$ of $25 \mathrm{~mm} \mathrm{MgCl}_{2}$ and $0.8 \mu \mathrm{L}$ of $2.5 \mathrm{~mm} \mathrm{dNTPs}$, 
in a final volume of $20 \mu \mathrm{L}$. The PCR cycles were one cycle of $2 \mathrm{~min}$ at $94{ }^{\circ} \mathrm{C}, 30 \mathrm{~s}$ at $65^{\circ} \mathrm{C}$ and 2 min at $72{ }^{\circ} \mathrm{C}$, followed by 10 cycles each of annealing temperature of 1 ${ }^{\circ} \mathrm{C}$ less than the former one, and 25 cycles of $30 \mathrm{~s}$ at $94{ }^{\circ} \mathrm{C}, 30 \mathrm{~s}$ at $56^{\circ} \mathrm{C}$, and $2 \mathrm{~min}$ at $72{ }^{\circ} \mathrm{C}$. The sequences of the selective amplification primers are shown in Table 2 . The first 17 nucleotides of these primers are identical to the preselective amplification primers, and the last two are random nucleotides added to the selective primers. The PCR products were mixed with $20 \mu \mathrm{L}$ of formamide dye (98\% formamide, 10 mм EDTA, $1 \mathrm{mg} \cdot \mathrm{mL}^{-1}$ bromophenol blue, $1 \mathrm{mg} \cdot \mathrm{mL}^{-1}$ xylene cyanol). The denatured PCR products were separated on 5\% denaturing polyacrylamide (20 acrylamide : 1 bis acrylamide, $7.5 \mathrm{~m}$ urea, $1 \mathrm{X}$ Tris borate EDTA-TBE buffer) standard sequencing gel (43 cm long) at $55 \mathrm{~W}$ for $2 \mathrm{~h}$. The gel was then dried and exposed to X-ray film for $\approx 72$ $\mathrm{h}$ at $-80^{\circ} \mathrm{C}$.

Genetic analysis. AFLP band patterns were converted into binary matrices (only the clear and reliable bands were scored: 1 for presence, 0 for absence of a band). Analysis of molecular variance (AMOVA) was performed using Arlequin software (Schneider et al., 2000). Genetic variation within populations was estimated by the percentage of polymorphic bands of all individuals within each population, and by average gene diversity (AGD; the average number of polymorphic bands in all pair-wise comparisons within populations). Genetic variation between groups was estimated by fixation index $\left(\mathrm{F}_{\mathrm{ST}}\right)$ values assessing the proportion of variation between population and the total variation.

Analysis of genetic relationship was performed using the program PHYLTOOLS (Buntjer, 2001). Nei index for each pair-wise comparison (number of shared bands/number of bands in either lane) was used for calculation of Nei values (Nei and Li, 1979). Neighbor-joining trees were calculated with the PHYLIP program NEIGHBOR (Felsenstein, 1999). Dendrograms were generated by cluster analysis using the unweighted pair group method using the arithmetic average (UPGMA) (Rohlf, 2000), and presented by TREEWIEW program (Page, 2000).

Clustering analysis of the various accessions was carried out using the STRUCTURE program (Pritchard et al., 2000). The STRUCTURE algorithm constructs genetic clusters from a collection of individual polymorphic genotypes. The software estimates the fraction of each individual genome belonging to each of the clusters.

\section{Results}

Characterization of Genetic Variation IN 'BarheE' and 'MEDJOOL' DATE TREES ORIGINATED FROM VARIOUS PROPAGATION METHODS. AFLP analysis was carried out on 29 'Barhee' and 28 'Medjool' accessions propagated by either offshoots or tissue
5' GATGAGTCCTGAGTAACAT 3' 5’GACTGCGTACCAATTCACT 3'

5’'GATGAGTCCTGAGTAACAG 3' 5’ GACTGCGTACCAATTCAAG

5' GATGAGTCCTGAGTAACAA 3' 5’ GACTGCGTACCAATTCACA 3'

5' GATGAGTCCTGAGTAACTA 3' 5' GACTGCGTACCAATTCACC 3'

5’' GATGAGTCCTGAGTAACTT 3' 5’ GACTGCGTACCAATTCAGG

5' GATGAGTCCTGAGTAACAC 3' 5’ GACTGCGTACCAATTCACT 3'

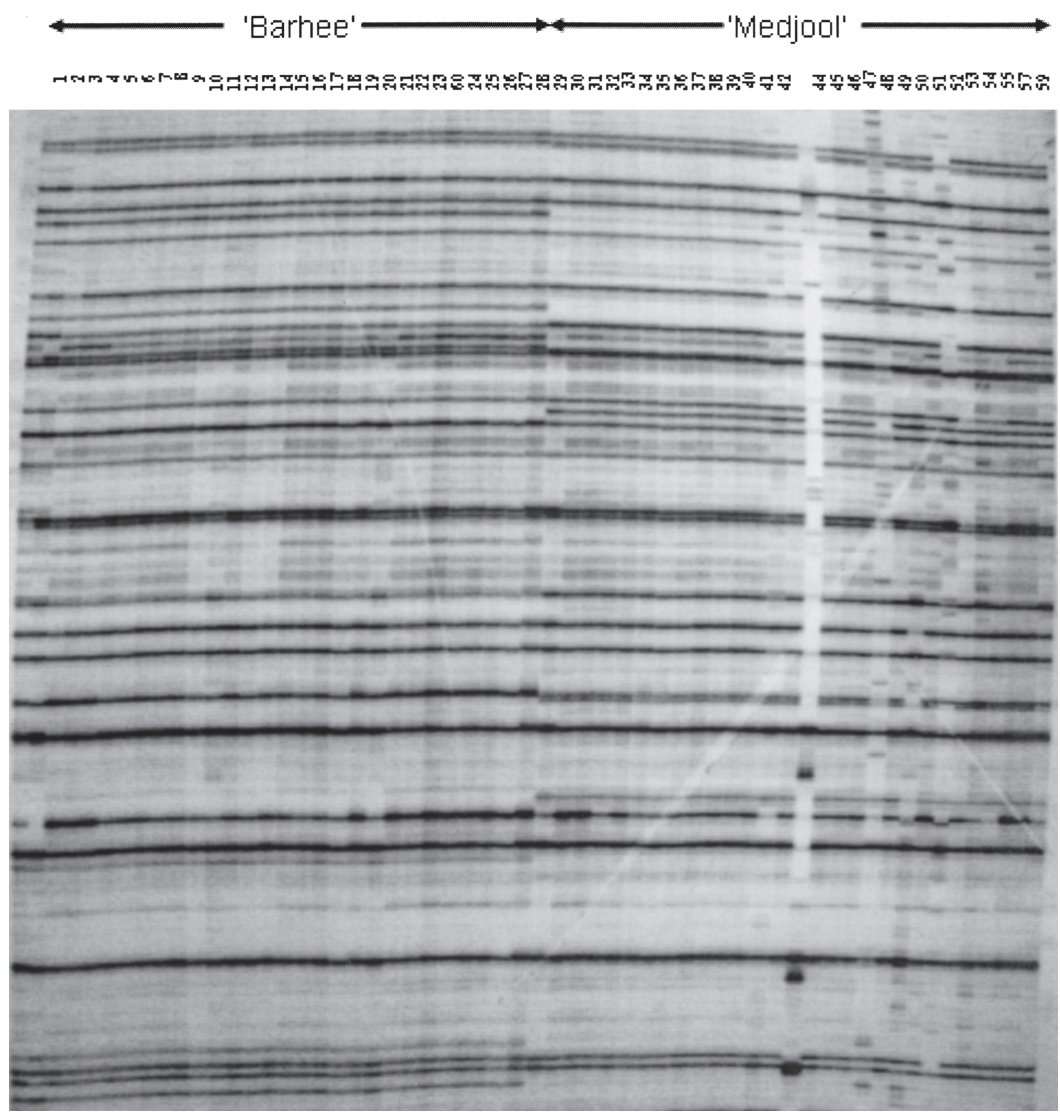

Fig. 1. Amplification fragment length polymorphism (AFLP) band pattern of 29 'Barhee' and 28 'Medjool' date accessions generated by primer set D. Accession numbers are detailed in Table 1.

culture (Table 1), using five different primer sets (A, B, C, D, and $\mathrm{O}$ ). The AFLP pattern generated by set $\mathrm{D}$ is shown in Fig. 1 . The total number of bands, the number of polymorphic bands, and the percentage of polymorphic bands generated by five primer sets are shown in Table 3. A total number of 317 AFLP bands were scored. AMOVA was carried out for the 'Barhee' and 'Medjool' accessions. Samples were grouped by their cultivar, propagation method (offshoot vs. tissue culture), and by the manufacturing tissue culture laboratory. The variation within groups, estimated 
Table 3. Characterization of the amplification fragment length polymorphism (AFLP) band patterns in date cultivars and male clones: number of polymorphic bands, percentage of polymorphic bands, and average gene diversity (AGD) values within groups generated for 29 'Barhee' and 28 'Medjool' date accessions, and for 33 male date palms. The total number of bands in the cultivars analysis was 317 generated by five primer sets (A, B, C, D, and O). The total number of bands in the male analysis was 354, generated by six primer sets (A, B, C, D, E, and O). Date clones were grown from offshoots (OS) or produced by different tissue culture companies [(TC) the producing laboratory is numbered in parentheses].

\begin{tabular}{|c|c|c|c|c|c|}
\hline Cultivar & $\begin{array}{l}\text { Source of } \\
\text { origin }\end{array}$ & $\begin{array}{c}\text { Trees } \\
\text { analyzed (no.) }\end{array}$ & $\begin{array}{c}\text { Polymorphic } \\
\text { bands (no.) }\end{array}$ & $\begin{array}{l}\text { Polymorphic } \\
\text { bands (\%) }\end{array}$ & $\begin{array}{l}\text { AGD } \\
\text { values }\end{array}$ \\
\hline Barhee & $\mathrm{OS}$ & $10\left(8^{z}\right)$ & $50\left(2^{z}\right)$ & $15.77\left(0.63^{z}\right)$ & $11.88\left(0.78^{z}\right)$ \\
\hline Barhee & $\mathrm{TC}(1)$ & 7 & 2 & 0.63 & 0.57 \\
\hline Barhee & TC (2) & 4 & 1 & 0.31 & 0.50 \\
\hline Barhee & TC (3) & 3 & 0 & 0 & 0.00 \\
\hline Barhee & TC (4) & 5 & 0 & 0 & 0.00 \\
\hline Total Barhee & & $29\left(27^{\mathrm{z}}\right)$ & $50\left(4^{z}\right)$ & $15.77\left(1.26^{z}\right)$ & $4.69(0.79 z)$ \\
\hline Medjool & OS & 10 & 3 & 0.94 & 0.75 \\
\hline Medjool & $\mathrm{TC}(5)$ & 4 & 15 & 4.73 & 7.83 \\
\hline Medjool & TC (2) & $9\left(8^{z}\right)$ & $68(27 \mathrm{z})$ & $21.45\left(8.52^{z}\right)$ & $18.66\left(9.32^{z}\right)$ \\
\hline Medjool & TC (6) & 3 & 11 & 3.47 & 7.33 \\
\hline Medjool & TC (7) & 2 & 3 & 0.94 & 3.00 \\
\hline Total Medjool & & $28\left(27^{\mathrm{z}}\right)$ & $84\left(43^{z}\right)$ & $26.49\left(13.56^{z}\right)$ & $9.21(5.97 z)$ \\
\hline \multicolumn{6}{|l|}{ Male clones } \\
\hline M11-M12 & $\mathrm{TC}(2)$ clone 1 & 2 & 0 & 0 & 0 \\
\hline M13-M16 & TC (2) clone 2 & 4 & 1 & 0.28 & 0.50 \\
\hline M17-M18 & TC (2) clone 3 & 2 & 4 & 1.13 & 4.00 \\
\hline M24-M25 & OS clone 4 & 2 & 0 & 0 & 0 \\
\hline M26-M27 & OS clone 5 & 2 & 0 & 0 & 0 \\
\hline M28-M29 & OS clone 6 & 2 & 3 & 0.85 & 3.00 \\
\hline M30-M31 & OS clone 7 & 2 & 0 & 0 & 0 \\
\hline M32-M33 & OS clone 8 & 2 & 1 & 0.28 & 1.00 \\
\hline $\begin{array}{l}\text { Total males (co } \\
\text { unknown indiv }\end{array}$ & $\begin{array}{l}\text { aining } 15 \\
\text { uals) }\end{array}$ & 33 & 261 & 73.72 & 51.97 \\
\hline
\end{tabular}

¿The above analysis was re-performed excluding the abnormal 'Barhee' offshoots (accessions 1 and 2) and the abnormal tissue culture-originated 'Medjool' (accession 47). The values excluding the abnormal accessions are presented in parentheses. by AGD, is presented in Table 3 . The variation among groups was calculated by $\mathrm{F}_{\mathrm{ST}}$ and shown in Table 4.

A high level of genetic variation was detected between the two cultivars Barhee and Medjool. Most of the variation was found between the 'Barhee' and 'Medjool' groups, as detected by the high $\mathrm{F}_{\mathrm{ST}}$ value between the two groups $\left(\mathrm{F}_{\mathrm{ST}}=0.9\right)$. AGD values within 'Barhee' accessions and within 'Medjool' accessions were 4.69 and 9.21 , respectively (Table 3 ).

Fifty bands $(15.8 \%)$ were polymorphic within 'Barhee' accessions. However, most of the polymorphic bands were specific to two very young offshoots (accessions 1 and 2). Only two polymorphic bands were detected within the rest of the offshoots. Two and one polymorphic bands were found in the 'Barhee' TC (1) and TC (2) groups, respectively, while within other 'Barhee' tissue culture groups no polymorphism was detected.

Eighty-four bands $(26.5 \%)$ were polymorphic among the 'Medjool' accessions. Tree number 47 had a unique AFLP band pattern and an abnormal phenotype. This tree generated offshoots, protruding several meters above the ground level, instead of producing inflorescences. The leaflets of this tree had a different shape relative to typical 'Medjool' leaflets (data not shown). Three polymorphic

Table 4. Fixation index $\left(\mathrm{F}_{\mathrm{ST}}\right)$ values calculated by analysis of molecular variance (AMOVA) for 29 'Barhee' and 28 'Medjool' date accessions. Date clones were grouped to trees propagated from offshoots (OS) or produced by different tissue culture companies [(TC) the producing laboratory is numbered in parentheses].

\begin{tabular}{|c|c|c|c|c|c|c|c|c|c|c|c|c|}
\hline & \multicolumn{6}{|c|}{ Barhee } & \multicolumn{6}{|c|}{ Medjool } \\
\hline & OS & $\mathrm{OS}^{\mathrm{z}}$ & $\mathrm{TC}(1)$ & $\mathrm{TC}(2)$ & $\mathrm{TC}(3)$ & $\mathrm{TC}(4)$ & OS & $\mathrm{TC}(5)$ & TC (2) & $\mathrm{TC}(2)^{\mathrm{z}}$ & $\mathrm{TC}(6)$ & TC (7) \\
\hline \multicolumn{13}{|l|}{ Barhee } \\
\hline OS & 0.00 & & & & & & & & & & & \\
\hline $\mathrm{OS}^{\mathrm{z}}$ & & 0.00 & & & & & & & & & & \\
\hline $\mathrm{TC}(1)$ & 0.00 & 0.13 & 0.00 & & & & & & & & & \\
\hline $\mathrm{TC}(2)$ & -0.08 & 0.11 & -0.16 & 0.00 & & & & & & & & \\
\hline $\mathrm{TC}(3)$ & -0.11 & 0.30 & 0.69 & 0.76 & 0.00 & & & & & & & \\
\hline $\mathrm{TC}(4)$ & -0.01 & 0.39 & 0.74 & 0.83 & 0.00 & 0.00 & & & & & & \\
\hline \multicolumn{13}{|l|}{ Medjool } \\
\hline OS & 0.92 & 0.99 & 0.99 & 0.99 & 0.99 & 0.99 & 0.00 & & & & & \\
\hline $\mathrm{TC}(5)$ & 0.86 & 0.96 & 0.96 & 0.94 & 0.94 & 0.95 & 0.24 & 0.00 & & & & \\
\hline TC (2) & 0.82 & & 0.86 & 0.83 & 0.82 & 0.85 & 0.09 & -0.03 & 0.00 & & & \\
\hline $\mathrm{TC}(2)^{\mathrm{z}}$ & & 0.93 & 0.93 & 0.91 & 0.90 & 0.92 & 0.13 & 0.01 & & 0.00 & & \\
\hline TC (6) & 0.86 & 0.97 & 0.97 & 0.96 & 0.95 & 0.97 & 0.38 & 0.02 & -0.06 & -0.01 & 0.00 & \\
\hline $\mathrm{TC}(7)$ & 0.86 & 0.99 & 0.99 & 0.98 & 0.99 & 0.99 & 0.84 & 0.38 & -0.04 & 0.09 & 0.30 & 0.00 \\
\hline
\end{tabular}

z'Barhee' offshoots excluding abnormal accessions 1 and 2 and 'Medjool' accession 47. 


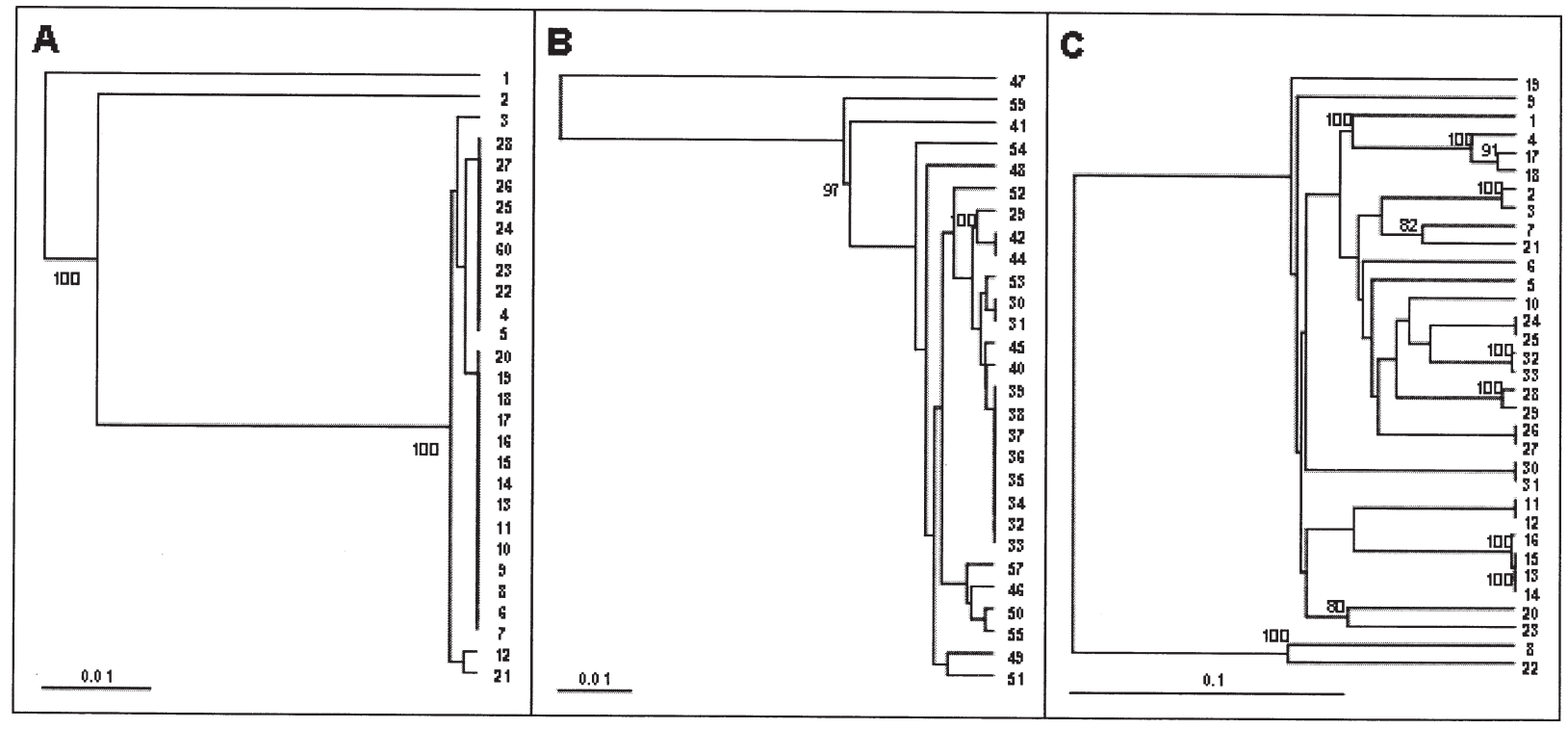

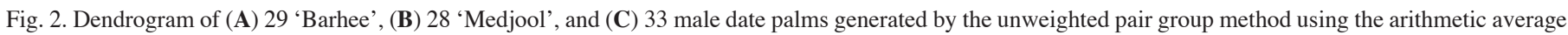

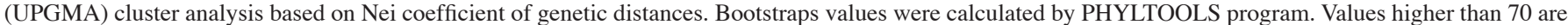
indicated.

bands were identified within 'Medjool' offshoots. The tissue culture-propagated 'Medjool' trees had a relatively high level of polymorphism. The highest level (68 polymorphic bands, AGD $=18.6$ ) was found within the TC (2) group.

Genetic relationships between the trees were assessed on the basis of the AFLP band patterns using Nei's coefficient of distance. The genetic distances detected between 'Barhee' and 'Medjool' accessions were very large relative to the distances of all accessions of a similar cultivar (data not shown). Dendrograms of 'Barhee' and 'Medjool' accessions are presented in Fig. 2A-B. The genetic distances within each cultivar were relatively small. Genetic distances within 'Medjool' accessions were larger then those observed between 'Barhee' accessions. Trees from the various sources of propagation (tissue culture or offshoots) were not clustered in the phylogenetic trees generated for 'Barhee' and 'Medjool'.

Clustering analysis was carried out by the STRUCTURE program using various numbers of groups (from $\mathrm{K}=$ 2 to $K=10$, according to the number of the analyzed 'Barhee' and 'Medjool' sources). All 'Barhee' and 'Medjool' accessions were separated into two distinct groups in all analyses. However, trees were not clustered based on their source or phenotype (Fig. 3).

GENETIC VARIATION AMONG TISSUE CULTURE- AND OFFSHOOT-ORIGINATED MALE TREES. Analysis of genetic variation was carried out on 33 male accessions. These included three groups (two pairs of accessions and one group comprising four individual trees), each originated from a specific tissue culture clone, five different pairs of trees propagated by offshoots from the same "mother" trees, and an additional 15 independent males propagated from offshoots (Table 1). Analysis was performed using six primer sets (A, B, C, D, E, and O). The total number of bands scored was 354. The number of polymorphic bands was $261(73.7 \%)$ and the average gene diversity was 52.0 (Table 3 ). Since the analysis was performed on 33 males representing 23 different clones, a high level of variation was expected.

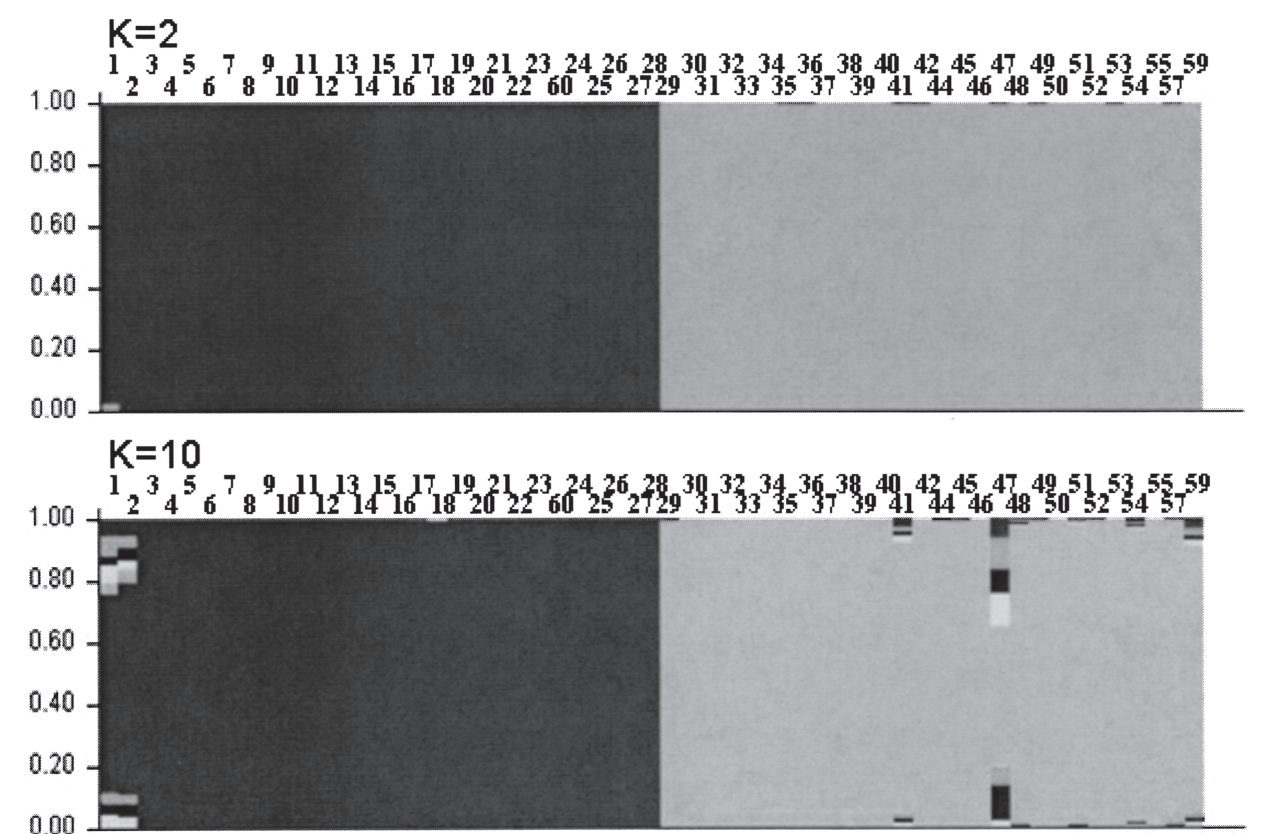

Fig. 3. Clustering analysis of amplification fragment length polymorphism (AFLP) band patterns of 29 'Barhee' and 28 'Medjool' date accessions by the STRUCTURE program. Clustering to two (upper panel) or 10 (lower panel) groups (K-number of groups) are presented. Each accession is represented by a vertical column and each group by a specific color. The relative relatedness of each accession to any group is demonstrated by the portion of the group color. 
Variation was also detected within accessions of the same clones originated from either offshoots or tissue culture. Polymorphic bands were identified in two out of the three tissue culture-originated clones from the same "mother" trees and in two out of five pairs of offshoots propagated from the same "mother" trees. However, the levels of polymorphism were low ( 0 to $1.1 \%$ polymorphic bands and average gene diversity values ranging between 0 and 4 ) (Table 3 ). A dendrogram of all male samples based on the AFLP polymorphism using Nei's coefficient of distance is presented in Fig. 2C.

Genetic VARIATION IN VARIOUS TISSUES OF INDIVIDUAL PLANTS. Analysis of genetic variation of various tissues of individual plantlets was performed. Variegated and nonvariegated regions of leaves, as well as root samples, were collected from two different, young, variegated 'Medjool' plants originated from tissue culture. Polymorphic bands were detected between variegated and normal leaf samples of the same plants, as well as between roots and leaf samples (Fig. 4). Three (1.875\%) and five $(3.125 \%)$ polymorphic bands, out of a total of 160 bands, were detected in the two trees, respectively. Variation was detected not only between the variegated and normal leaf sections, but also between either leaf sections and root samples. The results indicate that these trees are chimeric not only to a single mutation (easily detected by variegation), but to several other mutations as well.

\section{Discussion}

AFLPanalysis allows the detection of polymorphism at multiple loci, generating a large number of reproducible DNA markers. In the current study, this method was applied for assessment of genetic variation in date palms, originated from offshoots or produced by several tissue culture laboratories. Genetic variation was detected at several levels: between various cultivars or male clones, between various accessions of the same cultivar, in "progenies" from specific trees propagated either by offshoots or through tissue culture, and in different tissues of individual plants.

Genetic Variation Between Cultivars. Analysis of genetic variation in accessions of two date palm cultivars, 'Medjool' and 'Barhee', carried out in the current study, revealed high levels of polymorphism (58.7\% polymorphic bands with an AGD value of 41.7). Most of the variation was identified between the 'Barhee' and 'Medjool' cultivars, as indicated by the high $\mathrm{F}_{\mathrm{ST}}$ value $\left(\mathrm{F}_{\mathrm{ST}}\right.$ $=0.9$ ). These results are in agreement with genetic distances between the two cultivars previously published (Cao and Chao, 2002; Sedra et al., 1998). The geographical distance between the traditional growing regions of the two cultivars ('Barhee' is from Iraq, while 'Medjool' originated in Morocco), explains these results.

A high level of genetic variation was also identified within male accessions (73.72\% polymorphic bands out of 354 total bands, AGD = 51.97). While traditional conservation of female cultivars is maintained by vegetative propagation, most male trees originated by sexual reproduction from seeds. Male trees were imported to Israel during the last century from several different countries, together with the elite female cultivars. The large genetic variation represents the expected large heterogeneity of the male date population in Israel (and most probably elsewhere). The variation can serve as the basis for selection of males on the basis of their phenotypic characteristics regarding the potential to improve yields and fruit quality.

A large fraction of the bands was monomorphic. Forty-one

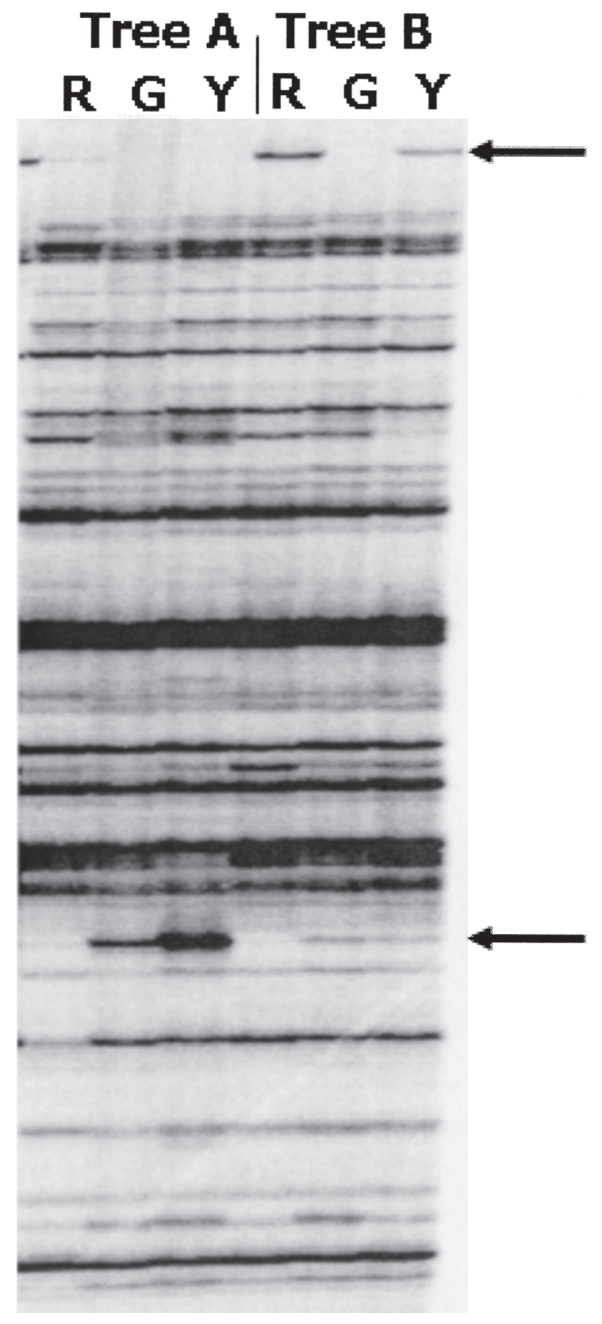

Fig. 4. A section of the amplification fragment length polymorphism (AFLP) band patterns of two young variegated off-types 'Medjool' date trees (trees A and $\mathrm{B})$, originated in tissue culture, generated using primer set $\mathrm{O}(\mathrm{R}=$ root; $\mathrm{Y}=$ yellow, variegated leaf section; $\mathrm{G}=$ normal green leaf section). Arrows indicate polymorphic bands detected within single trees.

percent of the bands were shared by all 'Barhee' and 'Medjool' accessions and $26 \%$ by most male trees. These bands are common to various cultivars, and may represent date palm-conserved bands.

GENETIC VARIATION WITHIN A CULTIVAR OR MALE CLONE PROPAGATED BY OFFSHOOTS. Within a single cultivar or male clone, a lower level of genetic variation was detected in trees propagated from either offshoots or tissue culture. The 'Barhee' and 'Medjool' trees originated from offshoots were collected from several plantations in different locations in Israel. Although relatively low, it is noteworthy that genetic variation was found within cultivars propagated vegetatively via offshoots. Variation in DNA fingerprints within trees of a specific cultivar were previously reported in 'Medjool', 'Deglet Noor', or 'Barhee' accessions using RAPD and RFLP(Corniquel and Mercier, 1994). Recently, genetic variation was also identified within 'Deglet Noor' and 'Medjool' accessions using AFLP (Devanand and Chao, 2003). In addition, we detected several mutational events occurring through a single generation of propagation by offshoot (Fig. 3 and Table 3: accessions M32-M33 and M28-M29; in the case of two additional male accessions (M2-M3), although no information 
on their relatedness exists, their high genetic similarity suggests that they also originated from one "mother" tree).

Analysis of 'Barhee' offshoots revealed very low levels of polymorphism. Two accessions (1 and 2) had distinct polymorphic patterns, and exhibited a relatively high level of polymorphism (15.1\% polymorphic bands). The two trees share many of the polymorphic bands. The two accessions are newly planted, very young offshoots originated from the same 'Barhee' orchard. Their young age prevented their phenotypic assessment. The overall uniformity of the other offshoots and the fact that these two accessions exhibit many 'Barhee'-specific bands suggest that they may be 'Barhee' seedlings mistakenly planted as offshoots. (This is known to be a common mistake in date palm practice due to difficulties in discrimination between offshoots and seedlings germinating very near the trunk of the "mother" trees.) If not, these findings contribute to the potential generation of genetic variation during development of offshoots.

Our findings detected limited levels of variation within 'Medjool' trees propagated through offshoots $(A G D=0.75)$. These results are in contrast to the high levels of polymorphism previously identified in 'Medjool' trees produced from offshoots in the United States (39\% polymorphic bands compared to only $3 \%$ in 'Deglet Noor' accessions) (Devanand and Chao, 2003). 'Medjool' is a Moroccan cultivar that was introduced to the United States in 1927 as nine offshoots removed from a single tree (Swingle, 1945). It may be that Devanand and Chao (2003) analyzed closely related, but genetically distinct 'Medjool' trees. Alternatively, it may be that the 'Medjool' offshoots in the United States have accumulated a significant number of genetic changes during their propagation in the last several decades.

ASSESSMENT OF GENETIC VARIATION IN TISSUE CULTURE-ORIGINATED TREES. The tissue culture-originated trees analyzed in this study were produced in several independent laboratories in several different countries. However, except for one abnormal tree (accession 47), we did not detect major genetic polymorphism specific to offshoots or tissue culture-originated trees. The various accessions could not be clustered (in the phylogenetic trees or by the STRUCTURE program) according to their tissue culture-producing laboratory, or according to their specific phenotype.

A relatively low level of polymorphism was identified within the 'Barhee' cultivar (excluding accessions 1 and 2) (1.26\% polymorphic bands, AGD = 0.79). Higher levels of genetic variation were detected within the 'Medjool' cultivar (excluding accession $47)(13.56 \%$ polymorphic bands, AGD $=5.97)$. The majority of variation within the 'Medjool' cultivar was found in trees originated from tissue culture. Most polymorphic trees were originated from a specific tissue culture source $(8.5 \%$ polymorphic bands and AGD $=9.32$ among normal-looking trees from TC 2). We assume that mutations occurred during the process of tissue culture propagation. These results, together with the high polymorphic levels of 'Medjool' trees propagated by offshoots found in the United States, suggest that this cultivar is "sensitive" to some unknown "conditions" or "agents." Mutations may be induced either in the field or during the tissue culture propagation process.

GENETIC VARIATION IN VARIOUS TISSUES WITHIN SINGLE PLANTS. Analysis of several tissues of two variegated 'Medjool' trees originated from tissue culture was performed. Polymorphic band patterns were detected in the variegated (yellow) vs. green sectors. Moreover, different polymorphic bands were identified in the green and variegated sectors of the two analyzed trees. Variegation can occur because of various mutations in the photosynthetic apparatus. Unexpectedly, additional polymorphism was detected between the root tissue and both leaf samples. The results indicated that these trees were chimeric not only to a single mutation (easily detected by variegation), but also to other mutations in various tissues. These results suggest that the tissue culture procedure induced the generation of multiple mutations.

USE OF MOLECULAR ANALYSES FOR EARLY DETECTION OF DATE OFF-TYPES. In the current limited analysis, the genetic variation found in 'Barhee and 'Medjool' was not correlated to the two most common off-type phenotypes detected in many tissue culture-originated trees: the phenotype of low levels of fruit setting, common in 'Barhee' trees, and the growth retardation phenotype of 'Medjool'. For the 'Barhee' phenotype, alleviation of symptoms was detected after several years (Cohen et al., 2004). It was estimated that $50 \%$ of the off-type trees reverted to normal within 10 years of planting, and symptoms in most other trees have been alleviated. Our preliminary analysis (only three accessions with the growth-retarded phenotype were analyzed) did not reveal a common molecular marker specific to either phenotype. However, the inability to detect polymorphism does not mean that it does not exist. These two phenotypes occur in mass numbers in tissue-cultured trees from specific sources, and are rare or absent in trees from other sources. The phenotype of the low level of fruit setting of the "Barhee' date palm is quite similar to the "mantled" phenotype of oil palm produced in tissue culture (Corley et al., 1986). This phenotype is characterized by low levels of fruit setting, formation of supernumerary carpels, alleviation of symptoms, and reversions of many trees to the normal phenotype. It has been suggested that an epigenetic affect by altered DNA methylation pattern, generated during the tissue culture stage, is the cause of the "mantled" phenotype (Jaligot et al., 2000, 2002; Matthes et al., 2001). If the above-mentioned phenotypes, the low level of fruit setting of 'Barhee', and the growth-retarded 'Medjool' in date palms are not controlled by changes in DNA, they may also be generated by epigenetic changes occurring during the tissue culture stage. Fine differences in the tissue culture conditions in various laboratories could be responsible for induction of these phenotypes. Modifications of tissue culture protocols for each cultivar could be the way to prevent mass formation of these common off-types.

The use of tissue culture techniques for date palms is rather new. This approach is required for the massive expansion of elite date cultivars in arid countries. Although in recent years many abnormal trees have been detected, this study suggests that most of the tissue culture-originated trees are genetically normal. Since epigenetic changes are probably involved in the formation of common off-types, additional molecular tools for identification of epigenetic effects, such as changes in patterns of DNA methylation, need to be developed. These may provide a tool for early detection of abnormal phenotypes, and for understanding the mechanism of their generation.

\section{Literature Cited}

Aitchitt, M., C.C. Ainsworth, and M. Thangavelu. 1993. A rapid and efficient method for the extraction of total DNA from mature leaves of the date palm (Phoenix dactylifera L.). Plant Mol. Biol. Rpt. 11:317-319.

Al-Khakifa, N.S. and E. Askari. 2003. Molecular phylogeny of date palm (Phoenix dactylifera L.) cultivars from Saudi Arabia by DNA fingerprinting. Theor. Appl. Genet. 107:1266-1270.

Al-Wasel,A.S. 2000. Vegetative and fruiting comparison of tissue culture derived and conventionally propagated date palm (Phoenix dactylifera L.) cv. Barhi trees. In Vitro Biol. Cellular Dev. Biol. 36:P-1010. 
Azeqour, M., K. Majourhat, and M. Baaziz. 2002. Morphological variations and isoenzyme polymorphism of date palm clones from in vitro culture acclimatized and established on soil in South Morocco. Euphytica 123:57-66.

Barrow, S.C. 1998. Amonograph of Phoenix L. (Palmae: Coryphoideae). Kew Bul. 53:513-575.

Buntjer, J.B. 2001. PHYLTOOLS phylogenetic computer tools. Ver. 1.3. Wageningen Univ., The Netherlands, 1 June 2004. <http://www. spg.wau.nl/pv/pub/pt/>.

Cao, B.R. and C.-C.T. Chao. 2002. Identification of date cultivars in California using AFLP markers. HortScience 37:966-968.

Cohen, Y., R. Korchinsky, and E. Tripler. 2004. Flower abnormalities cause abnormal fruit setting in tissue culture propagated date palm (Phoenix dactylifera L.). J. Hort. Sci. Biotechnol. 79:1007-1013.

Corley, R.H.V., C.H. Lee, L.H. Law, and C.Y. Wong. 1986. Abnormal flower development in oil palm clones. Planter, Kuala Lumpur 62:233-240.

Corniquel, B. and L. Mercier. 1994. Date palm (Phoenix dactylifera L.) cultivar identification by RFLP and RAPD. Plant Sci. 101:163-172.

Devanand,P.S. and C.T.Chao. 2003. Genetic variation within 'Medjool' and 'Deglet Nur' date (Phoenix dactylifera L.) cultivars in California detected by fluorescent-AFLP markers. J. Hort. Sci. Biotechnol. 78:405-409.

Djerbi, M. 2000. Abnormal fruiting of the date palm derived from tissue culture. Proc. Date Palm Intl. Symp., Windhoek, Namibia. p. 73

Felsenstein, J. 1999. PHYLIP, phylogeny inference package. Ver. 3.5c. Univ. of Washington, 20 June 2004. <http://evolution.genetics.washington.edu/phylip.html>.

Jaligot, E., T. Beule, and A. Rival. 2002. Methylation-sensitive RFLPs: Characterisation of two oil palm markers showing somaclonal variation-associated polymorphism. Theor. Appl. Genet. 104:1263-1269.

Jaligot, E., A. Rival, T. Beule, S. Dussert, and J.L. Verdeil. 2000. Somaclonal variation in oil palm (Elaeis guineensis Jacq.): The DNA methylation hypothesis. Plant Cell Rpt. 19:684-690.

Kaeppler, S.M., H.F. Kaeppler, and Y. Rhee. 2000. Epigenetic aspects of somaclonal variation in plants. Plant Mol. Biol. 43:179-188.

Kashkush, K., J. Fang, E. Tomer, J. Hillel, and U. Lavi. 2001. Cultivar identification and genetic map of mango (Mangifera indica). Euphytica 122:129-136.

Matthes, M., R. Singh, S.C. Cheah, and A. Karp. 2001. Variation in oil palm (Elaeis guineensis Jacq.) tissue culture-derived regenerants revealed by AFLPs with methylation-sensitive enzymes. Theor. Appl.
Genet. 102:971-979.

McCubbin, M.J., J. Van Staden, and A. Zaid. 2000. A Southern African survey conducted for off-types on date palms produced using somatic embryognesis. Proc. Date Palm Intl. Symp., Windhoek, Namibia. p. $68-72$.

Nei, M. and W.H. Li. 1979. Mathematical model for studying genetic variation in terms of restriction endonucleases. Proc. Natl. Acad. Sci. USA. 76:5269-5273.

Page, R.D.M. 2000. TREEWIEW, Tree drawing software for Apple Macintosh and Microsoft Windows. Ver. Univ. of Glasgow, Glasgow, Scotland, U.K. 20 June 2004. <http://taxonomy.zoology.gla.ac.uk/ $\mathrm{rod} / \mathrm{rod} . \mathrm{html}>$.

Pritchard, J.K., M. Stephens, and P. Donelly. 2000. Interference of population structure from multilocus genotype data. Genetics 155:945-959.

Rohlf,F.J. 2000. NTSYSpc, numerical taxonomy and multivariate analysis system, user guide. Ver. 2.1. Exeter Software, Setauket, N.Y.

Saker, M.M., S.A. Bekheet, H.S. Taha, A.S. Fahmy, and H.A. Moursy. 2000. Detection of somaclonal variations in tissue culture-derived date palm plants using isoenzyme analysis and RAPD fingerprints. Biol. Plant. 43:347-351.

Saker, M.M. and H.A. Moursi. 1999. Molecular characterization of Egyptian date palm cultivars: RAPD fingerprints. Arab J. Biotechnol.:71-78.

Schneider, S., D. Roessli, and L. Excoffier. 2000. ARLEQUIN, a software for populations genetic data analysis. Ver. 2.0. 20 June 2004. < http://anthro.unige.ch/arlequin>.

Sedra, M.H., P. Lashermes, P. Trouslot, M.C. Combes, and S. Hamon. 1998. Identification and genetic diversity analysis of date palm (Phoenix dactylifera L.) varieties from Morocco using RAPD markers. Euphytica 103:75-82.

Swingle, W.T. 1945. Introduction of the Medjhool date from Africa into the United States. Date Growers' Inst. 22:15-16.

Vorster, B.J., K.J. Kunert, and C.A. Cullis. 2002. Use of representational difference analysis for characerization of sequence between date palm varieties. Plant Cell Rpt. 21:271-275.

Vos, P., R. Hogers, M. Bleeker, M. Reijans, T. Lee, M. Hornes, F.A., J. Pot, J. Peleman, M. Kuiper, and M. Zabeau. 1995. AFLP: A new technique for DNA fingerprinting. Nucleic Acids Res. 23:4407-4414.

Zaid, A. and P.F. De Wet. 1999. Date palm propogation, p. 74-106. In: A. Zaid (ed.). Date palm cultivation. Food Agr. Org., Rome. 